\title{
ULTRASONIC STUDIES OF MOLECULAR INTERACTIONS IN THE SOLUTION OF ANALGIN DRUG AT 303K
}

\author{
R. R. Naik , S. V. Bawankar, O. A. Mahodaya \\ Department of Chemistry, Jankidevi Bajaj College of Science, Jamnalal \\ Bajaj Marg, Civil Lines Wardha \\ Corresponding author E-Mail: ritunaik912@rediffmail.com, \\ bawankarsv@gmail.com
}

\begin{abstract}
Analgin (Novalgin) is a type of analgesic which also has antipyretic properties. In the present study ultrasonic velocity $(\mathrm{U})$, density $(\rho)$ and viscosity $(\eta)$ have been measured at frequency $1 \mathrm{MHz}$ in the binary mixtures.The measured value of ultrasonic velocity, density and viscosity have been used to estimate the acoustical parameters namely adiabatic compressibility $(\beta a)$, relaxation time $(\tau)$, acoustic impedance $(z)$, free length (Lf), free volume (Vf) and internal pressure (Pi), Wada's constant to investigate the nature and strength of molecular interaction in the binary mixture with water. The obtained results support the occurrence of complex formation, molecular association through intermolecular hydrogen bonding in the binary liquid mixtures.
\end{abstract}

Key Words: Ultrasonic velocity, analgin, molecular interaction

\section{Introduction}

Ultrasound refers to sound waves of such a high frequency that it cannot be heard. High resolution ultrasound imaging has been used for determination of melanoma invasion depth in vivo for preoperative staging purposes [1-2]. Now a days ultrasonic technology is employed in a wide range of applications in medicine, biology, industry, material science, agriculture, oceanography, sonochemistry research etc. due to its non-destructive nature [3-10].

These waves have also been used to extract and release intracellular enzymes such as invertase, to promote enzyme release, enhance productivity in biological processes [11] etc. In field of agriculture, ultrasound waves have been utilized extensively in chemical additives 
(fertilizers and plant protection preparations) for improving the production yield of food produced. In material chemistry, ultrasound waves have been useful in the preparation of biomaterials, protein microspheres, in the modification of polymers and polymer surfaces etc. [12-17].

Much work has been done in solutions of polymers [18-23], amino acids [24-25] and other electrolytes [26-33]

The acoustic waves with frequencies of about $20 \mathrm{KHz}$ and above are known as ultrasonic waves. The velocity of sound in air and liquid is $330 \mathrm{~m} / \mathrm{s}$ and $1200 \mathrm{~m} / \mathrm{s}$ respectively. The shortest ultrasonic waves therefore have wave length of the order of visible light. The measurement of ultrasound refers to sound waves of such a high frequency that it cannot be heard. The measurement of sound velocity is simple in ultrasonic waves and therefore velocity measurement in small amount of samplecan be determined very accurately and easily.In the recent years, ultrasonic waves have acquired status of an important probe,for the study of structures and properties of matter. In the field of technology, the waves are being used for detection of flaws, testing of material, mechanical cleaning of surface etc. In basic science they are used to provide information about the behavior of the microscopic particles of matter. The observation and dispersion of ultrasonic wave provides information on the relaxation process and molecular interaction in the liquid. Such information is of very importance for the understanding of the liquid state. A large amount of work has been done on the absorption of ultrasonic waves in liquid. The study of ultrasonic waves in binary mixture of liquid shows the ultrasonic wave velocities and their derived excess parameters can be used to determined the relative strength of homo and hetero-moleculer interaction in it. The above mentioned application of ultrasonic waves in basic science and technology are primarily due to their dependence on molecular structures and types of 
constituents in the medium. The ultrasonic wave velocity in number of liquids thus differs according to its purity [34-38].

\section{Materials and Methods}

The ultrasonic velocity(U) have been measured on ultrasonic interferometer Mittal Model-F-05 with an accuracy of $0.1 \%$.The viscosities ( $\eta$ ) of binary mixtures were determined using Ostwald's viscometer by calibrating with double distilled water with an accuracy of $\pm 0.001 \mathrm{~Pa}$. Sec. The density ( $\rho$ ) of these binary solution was measured accurately using $25 \mathrm{ml}$ specific gravity bottle in an electronic balance precisely. Before measuring the velocity of particular sample, the interferometer was adjusted and its accuracy was determined. For this, water and Analgin binary mixture was taken in the measuring cell, for the purpose of calibration of instrument. The current in the microammeter was adjusted to $40 \mu \mathrm{A}$ for maximum deflection and suitable adjustments were made for the minimum. The ultrasonic velocity was calculated .The frequency of ultrasonic wave is $1 \mathrm{MHz}$.

1.Ultrasonic velocity $(\mathbf{u})$ :The relation used to determine the ultrasonic velocity is given by, $\mathrm{u}=\mathrm{f} \times \lambda \mathrm{ms}^{-1}$

Where, f - Frequency of ultrasonic waves, $\lambda$ - Wave length

2. Adiabatic compressibility (k): Adiabatic compressibility which is defined as, $\mathrm{K}=\left(1 / \mathrm{v}^{2} \rho\right) \mathrm{kg}^{-1} \mathrm{~ms}^{2}$

Where, $\mathrm{u}$ - Ultrasonic velocity, $\rho$ - Density of the solution

3. Free volume $\left(\mathbf{V}_{\mathbf{f}}\right)$ : Free volume in terms of the ultrasonic velocity (u) and the viscosity of the liquid (n) calculated by formula, $\mathrm{Vf}=(\mathrm{M}$ $\mathrm{u} / \mathrm{k \eta})^{3 / 2} \mathrm{~m}^{3}$

Where, $\mathrm{M}$ is the molecular weight and ' $\mathrm{k}$ ' is a temperature independent constant equal to $4.28 \times 10^{9}$ for all liquids. 
4. Acoustic impedance (Z): The acoustic impedance is computed by the formula

$Z=\mathrm{u} \times \rho \mathrm{kg} \mathrm{m}^{-2} \mathrm{~s}^{-1}$

5. Free length (Lf): It is calculated on using formula,

$\mathrm{L}_{\mathrm{f}} \quad=(\mathrm{K} \sqrt{\mathrm{K}})$

$\mathrm{K}$ - Jacobson temperature dependent constant defined as $\mathrm{K}=(93.875+$ $0.345 \mathrm{~T}) \times 10^{-8}$,

$\mathrm{K}=$ Adiabatic compressibility.

6. Attenuation $\left(\mathbf{a} / \mathbf{f}^{2}\right)$ : It is calculated by,

$\mathrm{a} / \mathrm{f}^{2}=8 \pi^{2} \eta / 3 \rho \mathrm{u}^{3}$

7. Viscous relaxation time (T ): It is calculated by using the relation, $\mathrm{T}=4 \eta / 3 \rho \mathrm{u}^{2}$

8. Rao's Constant (R):Rao's constant is calculated by using formula, $R=V \cdot v_{3}^{1} \quad$ or $\quad R=\left(\frac{M}{\rho}\right) v_{3}^{1}$

$\mathrm{M}=$ Molecular Weight.

9.Wada constant (W): It was calculated by formula, $\mathrm{W}=\mathrm{M} \cdot \mathrm{K}^{-1 / 7 / \rho}$

10. Internal pressure (Mi): On using below cited formula Internal pressure is calculated,

$\Pi i=b R T\left[\frac{k}{v}\right]^{1 / 2} \frac{\rho_{3}^{2}}{M_{6}^{7}}$

11.Molar volume: It is the ratio of density $\&$ molecular weight

$\mathrm{Vm}=\frac{\mathrm{M}}{\rho}$

12. Cohesive energy $(C E)$ : Cohesive energy is calculated by formula quoted below,

$C \mathrm{E}=\Pi i \mathrm{Vm}$ 


\section{Result and Discussion}

The measured values of ultrasonic velocity, density and related thermo acoustical parameters of Analgin with water at $303 \mathrm{~K}$ temperatures in different concentrations temperatures in different concentrations are shown in table1 and 2 .The variation of acoustical parameters with concentrations and temperature is shown graphically in fig. 1 to 14 .

Table 1:- Ultrasonic velocity, Density, Viscosity, Adiabatic compressibility, Intermolecular free length, Free volume, Rao's constant of different \% concentration of solution of compounds in water at ,303 $\mathrm{K}$

Solution of Analgin in water at $303 \mathrm{~K}$

\begin{tabular}{|c|c|c|c|c|c|c|c|}
\hline $\begin{array}{l}\text { Concentratio } \\
\mathbf{n}(\%)\end{array}$ & $\begin{array}{l}\text { Densi } \\
\text { ty } \\
\text { (Kgm- } \\
\text { 3) }\end{array}$ & $\begin{array}{l}\text { Viscosi } \\
\text { ty } \\
\times 10^{-3} \\
\left(\mathrm{Nsm}^{-2}\right)\end{array}$ & $\begin{array}{l}\text { Ultraso } \\
\text { nic } \\
\text { Velocity } \\
(\mathrm{m} / \mathrm{s})\end{array}$ & $\begin{array}{l}\text { Adiabatic } \\
\text { compressibil } \\
\text { ity } \times 10^{-10} \\
\left(\mathrm{~m}^{2} / \mathrm{N}\right)\end{array}$ & \begin{tabular}{lr}
\multicolumn{2}{l}{ Intermolecu } \\
lar & free \\
length & $\times 10^{-}$ \\
11 (m) &
\end{tabular} & $\begin{array}{l}\text { Free } \\
\text { Volu } \\
\text { me } \\
\text { x10-3 } \\
\left(\mathrm{m}^{3}\right. \\
\left.\mathrm{mol}^{-1}\right)\end{array}$ & $\begin{array}{l}\text { Rao's } \\
\text { consta } \\
\text { nt }\end{array}$ \\
\hline 0.0125 & 989.6 & 1.6323 & 1498 & 4.503 & 4.2103 & $\begin{array}{l}19.10 \\
2\end{array}$ & 3.854 \\
\hline 0.025 & 990.8 & 1.6721 & 1499 & 4.492 & 4.2052 & $\begin{array}{l}18.44 \\
2\end{array}$ & 3.850 \\
\hline 0.05 & 991.6 & 1.7095 & 1501 & 4.476 & 4.1977 & $\begin{array}{l}17.37 \\
6\end{array}$ & 3.849 \\
\hline 0.1 & 994.8 & 1.7428 & 1502 & 4.455 & 4.1879 & $\begin{array}{l}17.38 \\
3\end{array}$ & 3.837 \\
\hline
\end{tabular}


Table. 2- Internal pressure, Acoustic impedence, Relaxation time, ultrasonic attenuation, cohessive energy and molar volume, Wada's constant, at $303 \mathrm{~K}$

Solutin of Analgin in water at $303 \mathrm{~K}$

\begin{tabular}{|c|c|c|c|c|c|c|c|}
\hline $\begin{array}{l}\text { Concentration } \\
(\%)\end{array}$ & $\begin{array}{l}\text { Interna } \\
1 \\
\text { pressur } \\
\text { e } \\
\times 10^{3}(\mathrm{~N} \\
\left.\mathrm{m}^{-2}\right) \\
\end{array}$ & \begin{tabular}{l} 
Acoustic \\
Impeden \\
\multicolumn{2}{l}{ ce $10^{6}$} \\
$\left(\mathrm{Kg}^{-1} \quad \mathrm{~m}^{2}\right.$ \\
$\left.\mathrm{S}^{-1}\right)$
\end{tabular} & $\begin{array}{l}\text { Relaxati } \\
\text { on time } \\
\text { (S) }\end{array}$ & $\begin{array}{l}\text { Ultrasoni } \\
\text { c } \\
\text { attenuati } \\
\text { on } \times 10^{-14} \\
\left(s^{2} m^{-1}\right)\end{array}$ & $\begin{array}{l}\text { Wada's } \\
\text { consta } \\
\text { nt } \times 10^{3}\end{array}$ & $\begin{array}{l}\text { Cohessi } \\
\text { ve } \\
\text { energy } \\
\text { x10 } \\
\text { (KJ/Mol } \\
\text { ) } \\
\end{array}$ & $\begin{array}{l}\text { Molar } \\
\text { volume } \\
\times 10-3 \\
\left(\mathrm{~m}^{3} / \mathrm{m}\right. \\
\text { ol) }\end{array}$ \\
\hline 0.0125 & 38.931 & 1.482 & 4.8331 & 1.292 & 7.213 & 13.1136 & $\begin{array}{l}336.84 \\
3\end{array}$ \\
\hline 0.025 & 39.422 & 1.485 & 4.9631 & 1.320 & 7.215 & 13.2629 & $\begin{array}{l}336.43 \\
5\end{array}$ \\
\hline 0.05 & 39.455 & 1.488 & 5.0922 & 1.343 & 7.219 & 13.2633 & $\begin{array}{l}336.16 \\
3\end{array}$ \\
\hline 0.1 & 40.314 & 1.494 & 5.2158 & 1.362 & 7.223 & 13.5084 & $\begin{array}{l}335.08 \\
2\end{array}$ \\
\hline
\end{tabular}

The following figures shows the variation of various acoustical parameters with concentration and temperature.

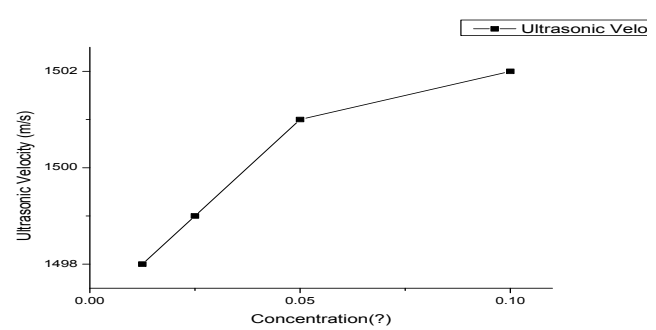

Figure:1-variation of ultrasonic velocity with concentration

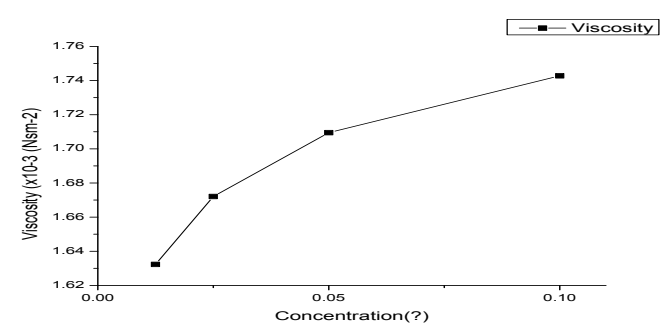

Figure:3-varation of viscosity with compressibility concentration

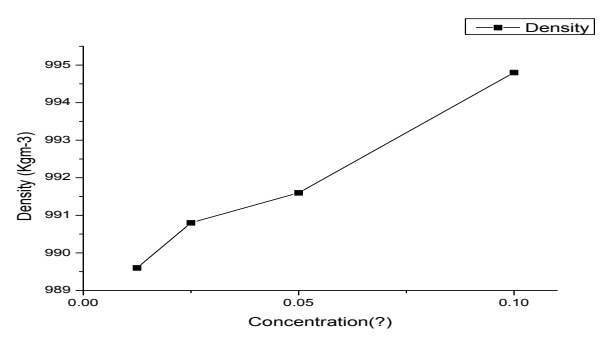

Figure:2-variation of density with concentration

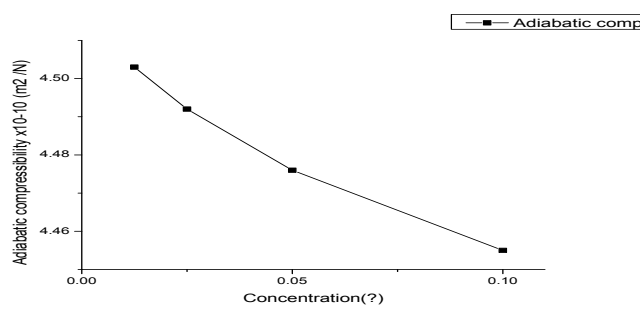

Figure:4-varation of adiabatic with concentration 

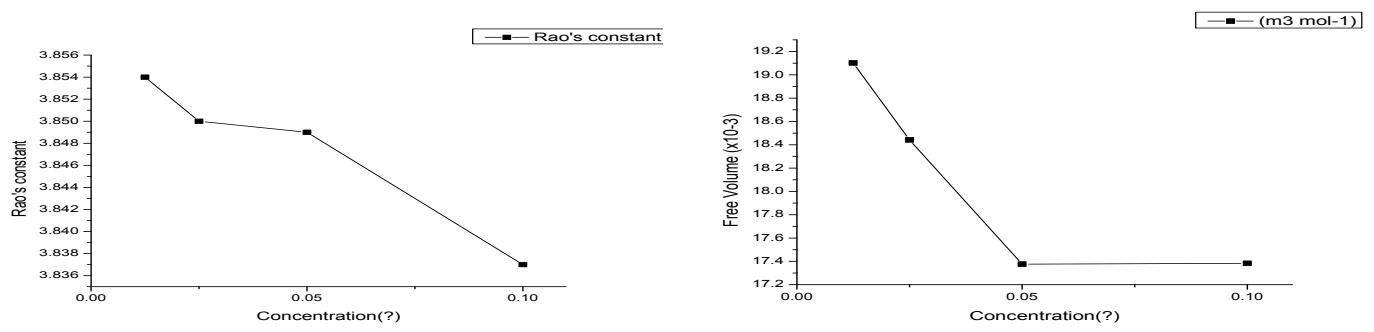

Figure:5-varation of Rao's constant with concentration

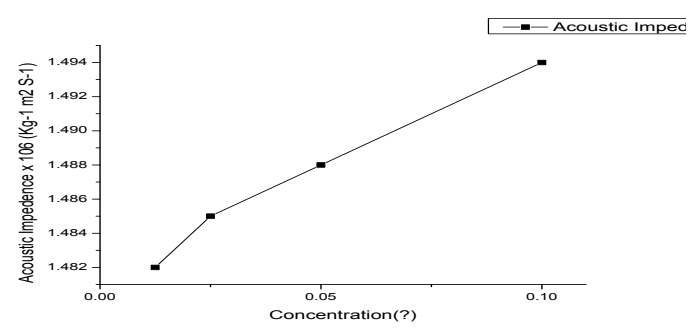

Figure:7-varation of acoustic impedence internal pressure with concentration

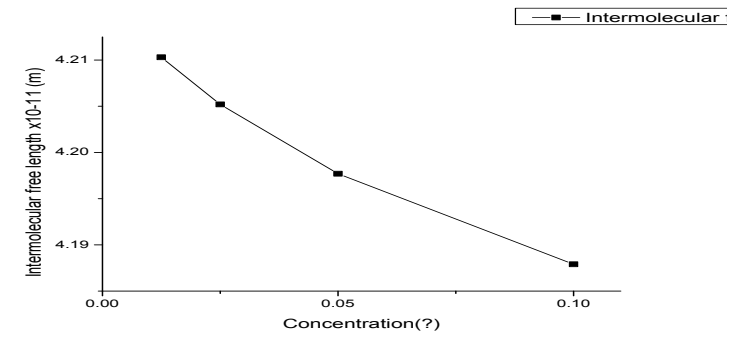

Figure:9-varation of intermolecular free constant length with concentration

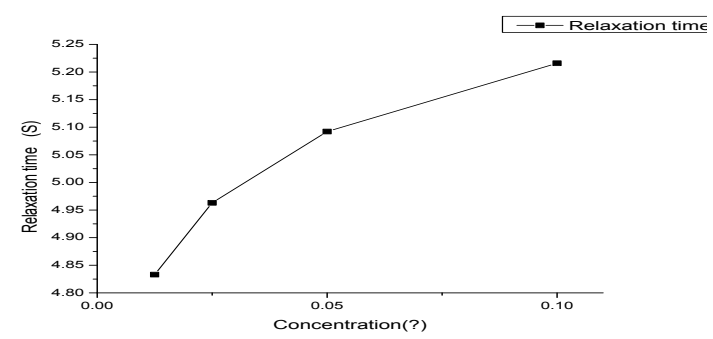

Figure: 11-varation of relaxation time with attenuation concentration

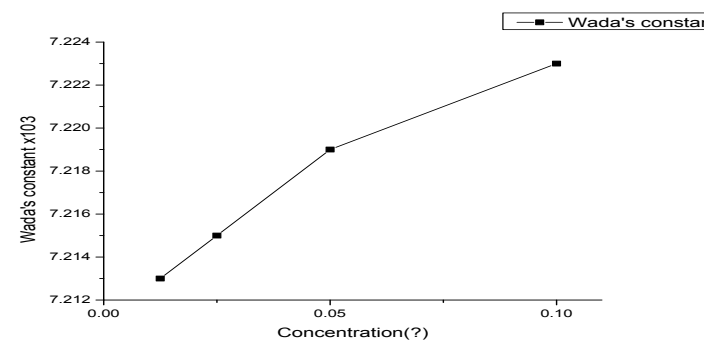

Figure:10-varation of Wada's with concentration

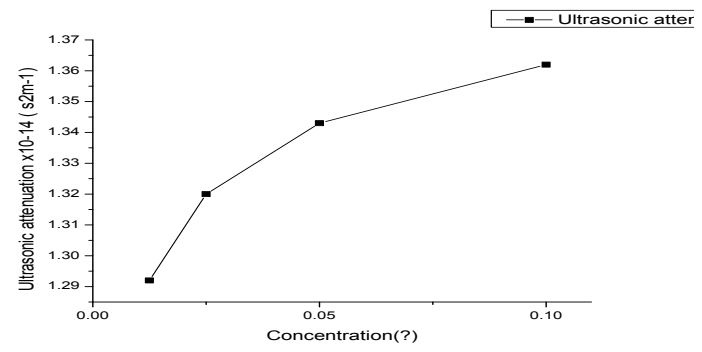

Figure:12-varation of ultrasonic with concentration 


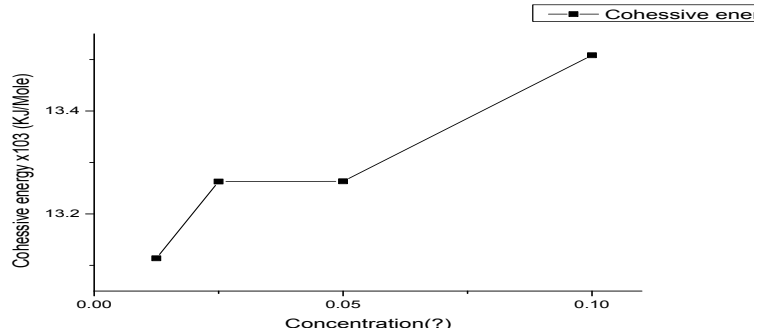

Figure: 13-varation of cohessive energy with concentration

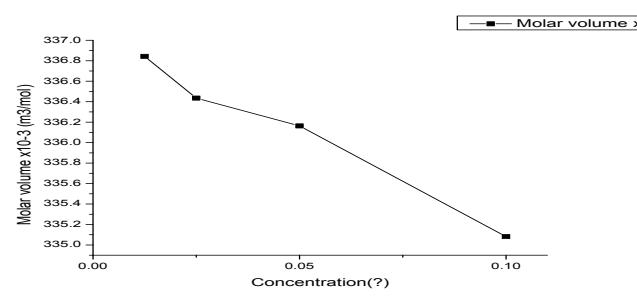

Figure:14-varation of molar volume with concentration

It is observed that ultrasonic velocity and acoustic impedance shows nonlinear increasing variation with increase in molar concentration. This indicates the complex formation and intermolecular weak association which may be due to hydrogen bonding. Thus complex formation can occurs at these molar concentrations between the component molecules. Adiabatic compressibility ( $\beta a)$ shows an inverse behavior compared to the ultrasonic velocity. Adiabatic compressibility decreases with increase in concentration of Analgin. The decrease in compressibility implies that there is an enhanced molecular association in the system with increase in solute concentration.

The opposite trend of ultrasonic velocity and adiabatic compressibility indicate association among interacting Analgin and water molecules. In the present system of aqueous Analgin, free length varies nonlinearly with increase in molar concentration which suggests the significant interaction between solute and solvent due to which structural arrangement is also affected.

Relaxation time decreases with increase in concentration. Nonlinear trend of density with concentration indicates the structure-making and breaking property of solvent due to the formation and weakening of $\mathrm{H}$ bonds. The free volume increases and internal pressure decreases with increases in molar concentration indicate the association through 
hydrogen bonding. It shows the increasing magnitude of interaction between the Analgin and water.

\section{Conclusion}

The acoustical parameters suggest the strong molecular interaction in the solution. Ultrasonic study of aqueous solution of Analgin at different concentrations give most useful information in understanding interaction of solute with solvent.

\section{Acknowledgement}

Authors are thankful to Dr. Om Mahodaya, principal, J.B.College of science Wardha for providing necessary facility to carry out this research work and also to Dr.P.V.Tekade for his kind cooperation.

\section{Reference}

E. W. Breitbart, W. Rehpenning, (1983), Hautkr 58, 975-87.

G. Gassenmaier, F. Kiesewetter, H. Schell, M. Zinner, (1990), Hautarzt $41,360-4$.

J. Blitz, (1963), Fundamentals of Ultrasonics, Butterworth \& Co. Ltd. London.

M. K. S. Suslick, (1988), Ultrasound: It's Chemical, Physical and Biological Effects, VCH, Weinheim.

T. J. Mason; Ed., (1990), Sonochemistry. The use of ultrasound in chemistry, Roy. Soc. Chem..

N., Kulkarni, B. Moudgil, M. Bhardwaj , (1994), Am. Cer. Soc. Cer. Bull $73,6$.

M. C., Bhardwaj, (1998), Proc. Am. Cer. Soc. 89.

T. Carneim, D. J. Green and M. C. Bhardwaj, (1999), Cer. Bull..

O. Kruger, T. L. Schulze, D. Peters, Ultra. (1999), Sonochem. 6, 123-28.

S. K. Najafi, g.ebrahimi, S. Behjati, (2008), defektoskopie 87. 
R. Gomes, M. J. Andrade ,M. Santos , S. Lima ,R. A. Gouveia , M. M. Ferreira, J. A. Silva, (2009), Cardiovascular Ultrasound, 7,36.

L. Palmowski, L. Simons and R. Brooks (2006),Water Sci. Tech.53(8), 281-288.

A. Van Itterbeek, (1959), Physica 25, 640.

B. Maxfield and C. Fortunko. (1983), Evalu., 41 ,12.

R.J. Dewhurst et al., (1988), Rev. Progress Quantitative Nondestructive Evalu.7B, 1615.

N.D. Patel and P.S. Nicholson, (1990), Rev. Prog. Quant. Nondestructive Evalu. 9.

K. S. Suslick, (1999), Rev. Mater. Sci., 29, 295-326.

A. Ali, A. K. Nain, V. K. Sharma, S. Ahmad, (2004), ternary mixtures through ultrasonic Phy. Chem. Liq., 42, 375-83.

B. T. Smith, W. P. Winfree, (1984), Ultra. Sympo. Proce, 2, 754-57.

J. N. Prassianakis, (1990), J. Appl. Poly. Sci.,39, 2031-41.

K. M. Rajkotia, S. Baluja, P. H. Parsania, (1997), Euro. Poly. J., 33,100507.

N. Saint-Pierre, Y. Jayet, (1998), Ultrasonics., 36, 783-88.

V. Kannappan, S. Mahendran, P. Sathyamoorthy, D. Roopsingh,(2001), J. Poly. Mat., 18, 409-16.

R. Gomes ,M. J. Andrade ,M. Santos, S. Lima ,R. A. Gouveia ,M. M. Ferreira, (2009), J. Aniceto, Cardio. Ultra.7,36.

S. P. Srivastava, S. Laxmi, (1970), 70, 219-23.

S. Kalahasti, C. S. Babu, A. V. Satyavati, (1990), Acustica. 71, 77-78.

K. S. Rao, B. R. Rao, (1958), J. Sci. Ind. Res. 17, 444-47.

V. H. Khan, K. V. (1974), Ramanaiah, Technology,21, 82-87. 
V. S. Soitkar, S. N. Jajooion, (1984), Acous. Lett,7, 191-5.

B. Manikiam, A. V. Narasimham, (1984), Ind. J. Pure Appl. Phy.22, 2933.

K. N. Mehrotra, M. Jain, (1992), Ind. J. Chem.31, 452-56.

V. K. Syal, V. Bhalla, S. Chauhan, (1995), Acustica 81, 276-78.

E. S. Balankina, A. K. Lyashchenko, (2002), J. Mole. Liqd., 101, 273-283.

R.T. Bhoyer and S.V. Letches: (1950), Physical Ultrasonics

S. Nithiyanantham \& L. Palaniappan (2005) Acta ciencia vol 31,533.

B. Rajamann etal (2005), Acta Ciencia.IndicaVol 21,555.

S. Prabhakar \& K. Rajgopal. (2005), J. pure appl.Ultrasonic,27,41-48.

A. S. Bahadur, MCS Subha \& K. C. Rao. (2006), J.Pure.Appl.Ultrasonic 23,26 . 